\title{
ZRSR2 wt Allele
}

National Cancer Institute

\section{Source}

National Cancer Institute. ZRSR2 wt Allele. NCI Thesaurus. Code C101121.

Human ZRSR2 wild-type allele is located in the vicinity of Xp22.1 and is approximately 33 $\mathrm{kb}$ in leng th. This allele, which encodes U2 small nuclear ribonucleoprotein auxiliary factor $35 \mathrm{kDa}$ subunit-related protein 2, plays a role in the regulation of RNA splicing. 